\title{
Effect of natural pozzolan on strength and temperature distribution of heavyweight concrete at early ages
}

\author{
Van Lam Tang ${ }^{1, *}$, Trong Chuc Nguyen ${ }^{1}$, Xuan Hung Ngo ${ }^{1}$, Van Phi Dang ${ }^{2}$, Boris Bulgakov ${ }^{1}$ \\ and Sophia Bazhenova ${ }^{1}$ \\ ${ }^{1}$ Moscow State University of Civil Engineering, Yaroslavskoe shosse, 26, Moscow, 129337, Russia \\ ${ }^{2}$ Hanoi University of Mining and Geology, 18 Pho Vien, Duc Thang, Bac Tu Liem, Ha Noi, Vietnam
}

\begin{abstract}
The benefits of using mineral additive as a partial replacement for cement in heavyweight concrete are discussed. This paper presents the strength development and temperature distribution of concrete using Class $\mathrm{F}$ of natural pozzolan (PU) sourced from Northern part of Vietnam. Based on the results of conducted studies, strengths of the natural pozzolan concrete at different ages were generally lower than those of control concrete. The 7-day compressive strengths of concrete with $20 \%$ PU decreases mostly by $30.1 \%$ and least by $12.3 \%$ at the age of 28 days in comparison with control concrete. However, natural pozzolan increases the workability of fresh concrete up to $16.67 \%$ in comparison with control concrete. By using the computer program Midas Civil, the maximum temperatures at the center of concrete block with $100 \%$ cement and of concrete block with $80 \%$ cement $+20 \%$ PU are $65.76^{\circ} \mathrm{C}$ and $52.44^{\circ} \mathrm{C}$, respectively, after 48 hours from the beginning of pouring. In addition, temperature difference between the central point and the environmental temperature of the control concrete are higher than heavyweight concrete using $20 \%$ PU. Meaningfully, the risk of through thermal cracking of heavyweight concrete without pozzolan are higher than heavyweight concrete PU to replace $20 \%$ of mass cement.
\end{abstract}

\section{Introduction}

Natural pozzolans are sourced from natural mineral and volcanic deposits. In Vietnam, some minerals like clay or shale require heat treatment to transform them into pozzolans, while others like volcanic ash exhibit pozzolanic behavior with minimal processing. Natural pozzolans have been used as a cementitious material for thousands of years. The natural pozzolan locally available in the Northern mountains of Vietnam is mainly Class F (ASTM 618 - 17a) [1]. It is often used in concrete as a partial replacement for cement in heavyweight concrete, mass concrete, Roller-Compacted concrete and other modern concrete, in structures such as hydraulic structures, gravity dams, bridge piers, and mass concrete footings for the high-rise buildings $[2,3]$.

${ }^{*}$ Corresponding author: lamvantang@gmail.com 
The benefits of using pozzolan and waste in concrete are threefold. Firstly, replacing a substantial part of the Portland cement by cheaper natural pozzolans or industrial by-products can gain a significant economy. Secondly, the environmental cost associated with cement blending and greenhouse gases emitted during Portland cement production is at lower level. Finally, there is an increase of product durability at later ages $[4,5]$. Various materials are added to the concrete mixture such as natural pozzolan, rice husk ash, and admixture to obtain binder mixtures. The character of the concrete is determined by quality of the binders [6].

The reduction of the heat of hydration to different extents by using active mineral additives have been documented in previous research [7-9]. According to [10-12], the temperature behaviour of concrete block at early ages is influenced by many parameters, such as the concrete properties, the amounts of cement and mineral additives, climatic factors, construction procedure, initial temperature of concrete mixture, and the chemical composition and fineness of the cement and additives. Heat is the result of the hydration reaction between the cement and water, so a higher content of cement results in a higher heat of hydration.

The replacement of cement by active mineral additives typically decreases the heat evolution due to a slower hydration reaction. Cement with smaller average particle size results in a greater surface area, and hence increases the hydration reactions and promotes the evolution of heat. Cement with a greater percentage of $\mathrm{C} 3 \mathrm{~A}$ and $\mathrm{C} 3 \mathrm{~S}$ will produce more heat as these compounds are involved in the early stages of hydration reaction.

In addition, the initial temperature of concrete mixture as well as of raw materials significantly effects on the maximum temperature at center of concrete block during the hardening process $[13,14]$.

This paper deals with the study of effects on the compressive strengths at different ages of concrete produced from partial replacement of Portland cement with natural pozzolan in Vietnam. In addition, the maximum temperature, spatial distribution of temperature and its evolution with time in body of concrete block are also discussed.

\section{Materials and Methods}

\subsection{Materials}

a) The cement used was ordinary Portland cement (PC) (40 Grade), manufactured at "Hoang Thach" factory (Vietnam), specific weight of $3.14 \mathrm{~g} / \mathrm{cm}^{3}$. The experimental results of physical and mechanical properties of cement are presented in Table 1 and the results of the chemical compositions are presented in Table 2.

Table 1. Physical and mechanical properties of Portland cement "Hoang Thach"

\begin{tabular}{|c|c|c|c|c|c|c|c|c|}
\hline \multirow{2}{*}{$\begin{array}{l}\text { Specific } \\
\text { weight } \\
\left(\mathrm{g} / \mathrm{cm}^{3}\right)\end{array}$} & \multirow{2}{*}{$\begin{array}{c}\text { Retained content } \\
\text { on sieve } 0.09 \\
\text { mm }(\%)\end{array}$} & \multirow{2}{*}{$\begin{array}{l}\text { Surface } \\
\text { area } \\
\left(\mathrm{cm}^{2} / \mathrm{g}\right)\end{array}$} & \multicolumn{2}{|c|}{$\begin{array}{l}\text { Time of setting } \\
(\mathrm{min})\end{array}$} & \multicolumn{3}{|c|}{$\begin{array}{c}\text { Compressive strength } \\
(\mathrm{MPa})\end{array}$} & \multirow{2}{*}{$\begin{array}{c}\text { Standard } \\
\text { consistency } \\
(\%)\end{array}$} \\
\hline & & & Initial & Final & 3 days & 7 days & 28 days & \\
\hline 3.14 & 5.1 & 3625 & 115 & 365 & 25.36 & 38.28 & 44.4 & 29.5 \\
\hline
\end{tabular}

b) Natural pozzolan (PU) of Vietnam (Figure 1), the specific weight of $2.81 \mathrm{~g} / \mathrm{cm}^{3}$, the volume of natural porous state of $980 \mathrm{~kg} / \mathrm{m}^{3}$ and water demand of $27.8 \%$. Retained content on sieve $0.09 \mathrm{~mm}$ is $12.5 \%$. The analysis results of chemical compositions of natural pozzolan are presented in Table 2 . 
Table 2. Chemical properties of Portland cement and natural pozzolan (Vietnam)

\begin{tabular}{|c|c|c|c|c|c|c|c|c|}
\hline \multirow{2}{*}{ Materials } & \multicolumn{8}{|c|}{ Average chemical composition (\%) } \\
\cline { 2 - 9 } & $\mathrm{SiO}_{2}$ & $\mathrm{Al}_{2} \mathrm{O}_{3}$ & $\mathrm{Fe}_{2} \mathrm{O}_{3}$ & $\mathrm{CaO}$ & $\mathrm{MgO}$ & $\mathrm{SO}_{3}$ & LOI & other \\
\hline Portland cement & 19.8 & 4.1 & 5.4 & 61.9 & 2.8 & 3.2 & 2.5 & 0.3 \\
\hline Natural pozzolan & 48.7 & 22.3 & 12.5 & 3.5 & 4.7 & 1.5 & 3.2 & 3.6 \\
\hline
\end{tabular}

c) Aggregate. Good quality river sand was used as a fine aggregate, which produced from the quartz sand (QS) of "Lo River" (Vietnam). The fineness modulus $\mathrm{M}_{\mathrm{K}}=3.0$, specific gravity and dry density are $2.65 \mathrm{~g} / \mathrm{cm}^{3}$ and $1650 \mathrm{~kg} / \mathrm{m}^{3}$. Crushed limestone (CL) from the quarry "Kien Khe" (Vietnam) was used as a coarse aggregate with the size of $5 \div 20 \mathrm{~mm}$. Its specific gravity and dry density are $2.68 \mathrm{~g} / \mathrm{cm}^{3}$ and $1540 \mathrm{~kg} / \mathrm{m}^{3}$.

d) Ordinary clean tap water (W) was used for both mixing concrete and curing of test specimens.

\subsection{Methods}

Calculation method of concrete mixture composition is applied in accordance with standard TCVN 9382 - 2012 (Vietnam). According to standard GOST 10181-2014 (Russian), the concrete mixture workability is determined by the standard slump cone with dimensions of 100x $200 \times 300 \mathrm{~mm}$. The compressive strength and tensile strength of heavyweight concrete are determined by Russian standard GOST 10180-2012. These test samples are demolded after 24 hours later casting and placed in a $20 \pm 5^{\circ} \mathrm{C}$ water curing tank until the experiments. The compressive strengths of heavyweight concrete are tested at the ages of 3, 7, 14 and 28 days. The concrete elasticity modulus is determined by the compressive strength value at 28 days by American standard ACI 318-2005. While, the Midas Civil computer program will calculate the temperature distribution in central of block concrete. Furthermore, the estimation of maximum temperature, which developed in mass concrete members, is determined by quick method of the Portland Cement Association's design and control of concrete mixtures.

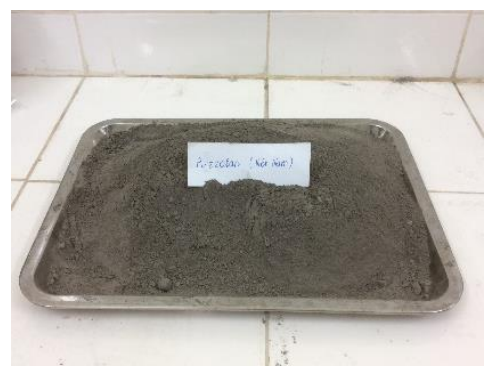

Fig. 1. Natural pozzolan of Vietnam

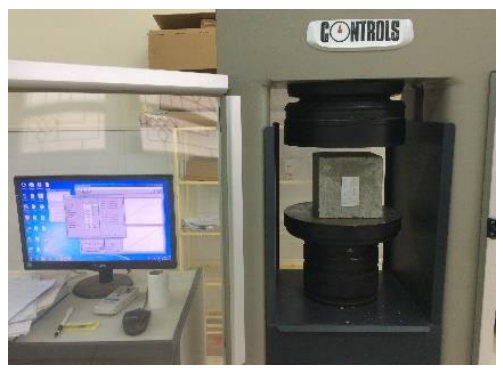

Fig. 2. Testing of specimen under compression

\section{Test results and Discussion}

\subsection{Mixture Proportioning}

It is necessary to determine the concrete mixture compositions for the heavyweight concrete production, which are intended for monolithic reinforced concrete buildings and constructions of the Northern part of Vietnam in the summer.

Compositions of heavyweight concrete in this work must possess:

1 . The fresh concrete effect on workability is determined by the slump of standard cone of $90 \div 150 \mathrm{~mm}$. 
2. The target mean strength was $40 \mathrm{MPa}$ for the control mixture with $100 \%$ Portland cement. The compressive strength of concrete is determined by using 150x150x150 mm cube specimens at the ages of 28 days of normal hardening (Figure 2).

3. Using natural pozzolan to replace $20 \%$ of mass Portland cement in concrete mixture.

4. Relative volume of entrapped air is $1 \%$.

\subsection{Effect of natural pozzolan on strengths of heavyweight concrete}

The mix proportion was done as per the standard TCVN 9382 - 2012 (Vietnam). The water to binder ratio was kept constant as 0.46 . Experimental results of concrete mixes properties and heavyweight concretes are presented in Tables 3 and 4.

Table 3. Mix compositions and properties of fresh concrete

\begin{tabular}{|c|c|c|c|c|c|c|c|c|c|}
\hline \multirow{2}{*}{$\begin{array}{c}\text { Compositions } \\
\text { of concrete mixture }\end{array}$} & \multicolumn{3}{|c|}{ Compositions of concrete mixture $\left(\mathrm{kg} / \mathrm{m}^{3}\right)$} & \multicolumn{3}{|c|}{ Properties of fresh concretes } \\
\cline { 2 - 11 } & PC & PU & BID & QS & CL & W & $\frac{W}{B I D}$ & $\begin{array}{c}\text { Average density } \\
\left(\mathrm{kg} / \mathrm{m}^{3}\right)\end{array}$ & $\begin{array}{c}\text { Slump } \\
(\mathrm{cm})\end{array}$ \\
\hline $100 \%$ cement & 490 & 0 & 490 & 545 & 1108 & 225 & 0.46 & 2368 & 12 \\
\hline $80 \%$ cement $+20 \%$ PU & 392 & 98 & 490 & 535 & 1108 & 225 & 0.46 & 2358 & 14 \\
\hline
\end{tabular}

Table 3 shows the comparative effects of addition of natural pozzolan on workability of concrete. It was observed that natural pozzolan increases the workability of fresh concrete upto $16.67 \%$ as compared to control concrete.

Table 4. Properties of concrete

\begin{tabular}{|c|c|c|c|c|c|c|c|}
\hline \multirow{2}{*}{$\begin{array}{l}\text { Compositions } \\
\text { of concrete } \\
\text { mixture }\end{array}$} & \multicolumn{4}{|c|}{$\begin{array}{l}\text { Average compressive strength } \\
\text { at different ages }(\mathrm{MPa})\end{array}$} & \multirow{2}{*}{$\begin{array}{c}\text { Average tensile } \\
\text { strength at the } \\
\text { age of } 28 \text { days } \\
(\mathrm{MPa})\end{array}$} & \multirow{2}{*}{$\begin{array}{c}\text { Elasticity } \\
\text { modulus of } \\
\text { concrete }\left(\mathrm{N} / \mathrm{m}^{2}\right)\end{array}$} & \multirow{2}{*}{$\begin{array}{l}\text { Average density } \\
\text { of concrete } \\
\left(\mathrm{kg} / \mathrm{m}^{3}\right)\end{array}$} \\
\hline & 3 days & 7 days & 14 days & 28 days & & & \\
\hline $100 \%$ cement & 24.3 & 33.6 & 41.3 & 43.1 & 3.34 & $3.1 .10^{10}$ & 2355 \\
\hline $\begin{array}{l}80 \% \text { cement }+ \\
20 \% \text { PU }\end{array}$ & 17.4 & 23.5 & 35.2 & 37.8 & 2.93 & $2.9 .10^{10}$ & 2352 \\
\hline
\end{tabular}

The compressive strength reduction, $\%$ of concrete sample composition at different ages are shown in Figure 3.

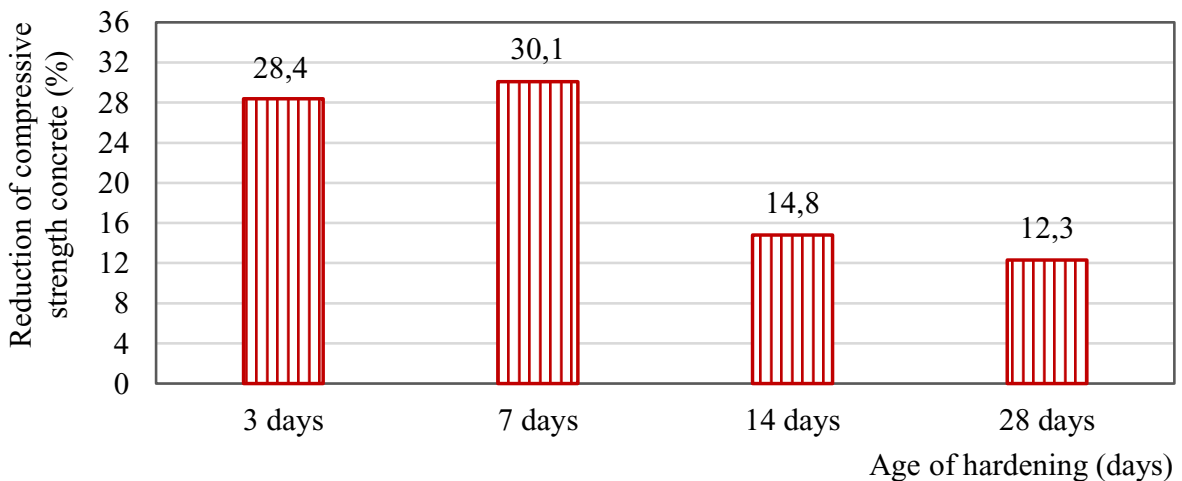

Fig. 3. Reduction of the compressive strength of concrete samples of composition $100 \%$ cement as compared to composition $80 \%$ cement $+20 \%$ PU at different ages 
From the Tables 3, 4 and Figure 3 of the experimental results, the following conclusions can be drawn:

1. The usage of natural pozzolan to replace $20 \%$ of the mass cement in concrete mixture can reduce the concrete sample strength at different ages. The concrete compressive strength of composition of $80 \%$ cement $+20 \%$ PU decreases mostly by $30.1 \%$ at the age of 7 days, and least by $12.3 \%$ at the age of 28 days in comparison to control concrete without pozzolan. However, all the concrete compressive strengths are higher than $35 \mathrm{MPa}$ at the age 28 days of curing.

2. Replacing a substantial part of Portland cement in concrete mixes will not only re-use existing waste which may have negative environmental impacts but also decrease concrete cost as well as improve concrete engineering properties during building construction in Vietnam. Furthermore, this article shows the effects of natural pozzolan on hydration heat of concrete by $20 \%$ cement replacement.

\subsection{Effect of natural pozzolan on temperature distribution of concrete}

The case study object is a monolithic concrete block of the high-rise building foundation, shaped rectangular box with $3.5 \mathrm{~m}$ length, $3 \mathrm{~m}$ width and $1.5 \mathrm{~m}$ thick, founded on a solid ground in the urban areas of Northern Vietnam in the summer.

\subsubsection{Finite element method of temperature field}

According to the studies [15], at any point of calculation field $\mathrm{R}$, the unstable temperature field $\mathrm{T}(\mathrm{x}, \mathrm{y}, \mathrm{z}, \tau)$ must satisfy the following continuous thermal conduction equation (1):

$$
\frac{\partial}{\partial x}\left(k_{x}(\mathrm{~T}) \frac{\partial T}{\partial x}\right)+\frac{\partial}{\partial y}\left(k_{y}(\mathrm{~T}) \frac{\partial T}{\partial y}\right)+\frac{\partial}{\partial z}\left(k_{z}(\mathrm{~T}) \frac{\partial T}{\partial z}\right)+G=\rho c \frac{\partial T}{\partial \tau},
$$

where: $\mathrm{T}$ - the material temperature $\left({ }^{0} \mathrm{C}\right)$;

$k_{x}(T), k_{y}(T), k_{z}(T)$ - the thermal conductivities $\left(W / m^{\circ} \mathrm{C}\right)$, dependent on temperature by three directions $\mathrm{x}, \mathrm{y}$ and $\mathrm{z}$, respectively;

$\mathrm{G}$ - the rate of internal heat generation (internal energy), per unit volume $\left(\mathrm{W} / \mathrm{m}^{3}\right)$;

$\mathrm{c}-$ the specific heat $\left(\mathrm{J} / \mathrm{kg} .{ }^{\circ} \mathrm{C}\right)$;

$\rho$ - the density concrete $\left(\mathrm{kg} / \mathrm{m}^{3}\right)$;

$\tau$ - time (day).

To solve equation (1), it is necessary to know two main types of boundary conditions which are Drichlet and Cauchy boundary [16]. These conditions are written respectively as:

$$
T=T_{p}, k_{x} \frac{\partial T}{\partial x} l_{x}+k_{y} \frac{\partial T}{\partial y} l_{y}+k_{z} \frac{\partial T}{\partial z} l_{z}+q+h\left(T_{s}-T_{f}\right)=0
$$

where: $T_{p}$ - the values of the nodal temperatures on the boundaries $\left({ }^{0} \mathrm{C}\right)$;

$\mathrm{q}$ - surface heat $\left(\mathrm{kcal} / \mathrm{m}^{3}\right)$;

$\mathrm{h}$ - film coefficient;

$\mathrm{T}_{\mathrm{s}}$ - temperatures at the boundary nodal points $\left({ }^{0} \mathrm{C}\right)$;

$\mathrm{T}_{\mathrm{f}}$-the ambient temperature $\left({ }^{0} \mathrm{C}\right)$;

$1_{\mathrm{x}}, 1_{\mathrm{y}}$ and $l_{\mathrm{z}}$ - the direction cosines of the outward normal to the surface under consideration on $\mathrm{x}, \mathrm{y}$ and $\mathrm{z}$ axes respectively

\subsubsection{Material Properties and Environmental Conditions}

The properties of heavyweight concrete without pozzolan and replaced $20 \%$ cement with pozzolan, which are used as input data for determining the distribution of temperature and maximum temperatures of the central concrete block during construction process in Northern 
Vietnam, are presented in Table 5. The amount of cement, average density, elastic modulus of concretes are given in Tables 3 and 4. A typical coefficient of thermal expansion of $0.75 .10^{-5} /{ }^{0} \mathrm{C}$ was adopted for concretes.

Table 5. Properties of the materials used in the thermal behavior analysis

\begin{tabular}{|c|c|c|}
\hline \multirow{2}{*}{ Properties } & \multicolumn{2}{|c|}{ Compositions of concrete mixture } \\
\hline & $100 \%$ cement & $80 \%$ cement $+20 \% \mathrm{PU}$ \\
\hline Thermal conductivity coefficient $\left(\mathrm{W} /\left(\mathrm{m} .{ }^{0} \mathrm{C}\right)\right.$ & 2.63 & 2.63 \\
\hline Specific heat coefficient $\left(\mathrm{J} / \mathrm{kg} .{ }^{0} \mathrm{C}\right)$ & 1.05 & 1.05 \\
\hline Mass density $\left(\mathrm{kg} / \mathrm{m}^{3}\right)$ & 2355 & 2352 \\
\hline $\begin{array}{lllll}\text { Boundary } 1 & \text { (free } & \text { contact with } & \text { air) } & \text { with } \\
\text { convection coefficient } & \left(\mathrm{W} / \mathrm{m}^{2} .{ }^{0} \mathrm{C}\right)\end{array}$ & 10.0 & 10.0 \\
\hline $\begin{array}{l}\text { Boundary } 2 \\
\text { convection coefficient }\left(\mathrm{W} / \mathrm{m}^{2} .{ }^{0} \mathrm{C}\right)\end{array}$ & 7.5 & 7.5 \\
\hline Elastic modulus $\left(\mathrm{N} / \mathrm{m}^{2}\right)$ & $3.1 .10^{10}$ & $2.9 .10^{10}$ \\
\hline Poisson's ratio [17] & 0.15 & 0.15 \\
\hline Thermal expansion Coefficient $\left(1 /{ }^{\circ} \mathrm{C}\right)[18]$ & $0.65 .10^{-5}$ & $0.65 .10^{-5}$ \\
\hline Maximum cement hydration heat at 28 days $(\mathrm{J} / \mathrm{g})$ & 309 & 260 \\
\hline Amount of cement $\left(\mathrm{kg} / \mathrm{m}^{3}\right)$ & 490 & 392 \\
\hline The concrete mixtures temperature of $\left({ }^{\circ} \mathrm{C}\right)$ & 20 & 20 \\
\hline
\end{tabular}

Heat of cement hydration in concrete as a function of time was obtained from several experiments performed in the laboratory. In accordance with [18], the heat of hydration produced with time for Portland cement with and without the addition of pozzolan are shown in Figure 4.

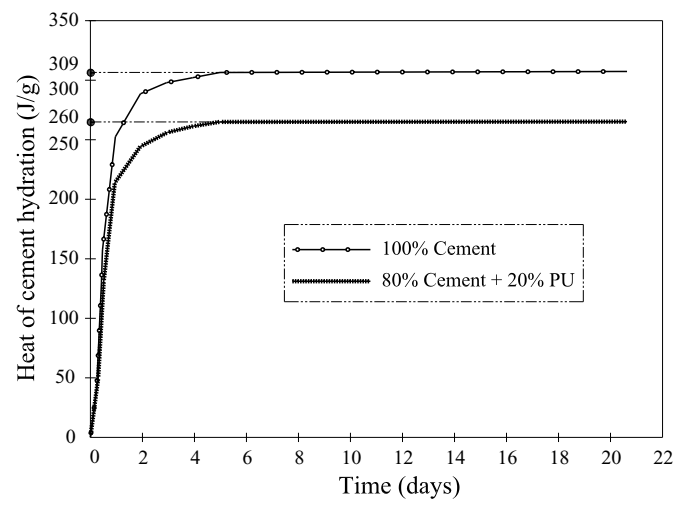

Fig. 4. Heat of hydration of Portland cement with different time

Figure 5 shows the boundary conditions for the thermal analysis. Two types of boundary are used, which are considered including boundary 1 (free contact with air) with convection coefficient value of $10 \mathrm{~W} / \mathrm{m}^{2} .{ }^{0} \mathrm{C}$ and boundary 2 (wood shuttering) with a value of 7.5 $\mathrm{W} / \mathrm{m}^{2}{ }^{0} \mathrm{C}[17]$

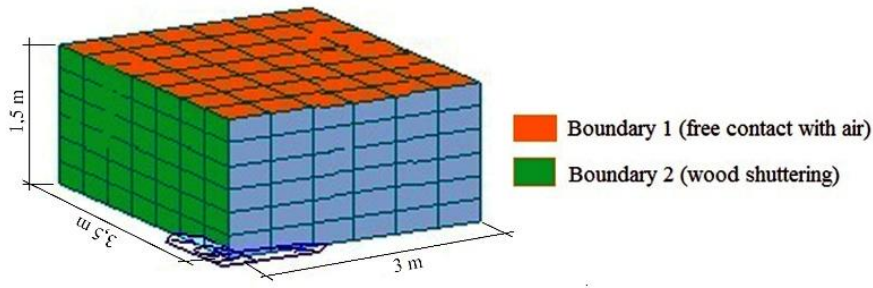

Fig. 5. Thermal boundary conditions and dimensions for temperature behaviour analysis of the concrete block 
According to the study [19], the summer temperature in Northern Vietnam change according to the equation (3):

$$
t_{\text {air }}=26.5+5 \sin \left(\frac{2 \pi \tau}{24}\right)\left({ }^{\circ} \mathrm{C}\right)
$$

where: $\mathrm{t}_{\text {air }}$ - daily average air temperature in the summer $\left({ }^{0} \mathrm{C}\right)$ and $\tau$ - time (hours).

In this work, the initial temperature of laying concrete mixtures, which depends on the concrete mixture temperature, is $20^{\circ} \mathrm{C}$. The initial temperature of the foundation is considered constant as $25^{\circ} \mathrm{C}$.

\subsubsection{Results of three-dimensional temperature distribution in body of concrete block}

Program Midas Civil determined the temperature distribution and maximum temperature at center of the concrete block, which designed for construction of the high-rise building foundation. The temperature evolutions at center of concrete block from the beginning of pouring until 16 days, are depicted in Figures 6 and 7.

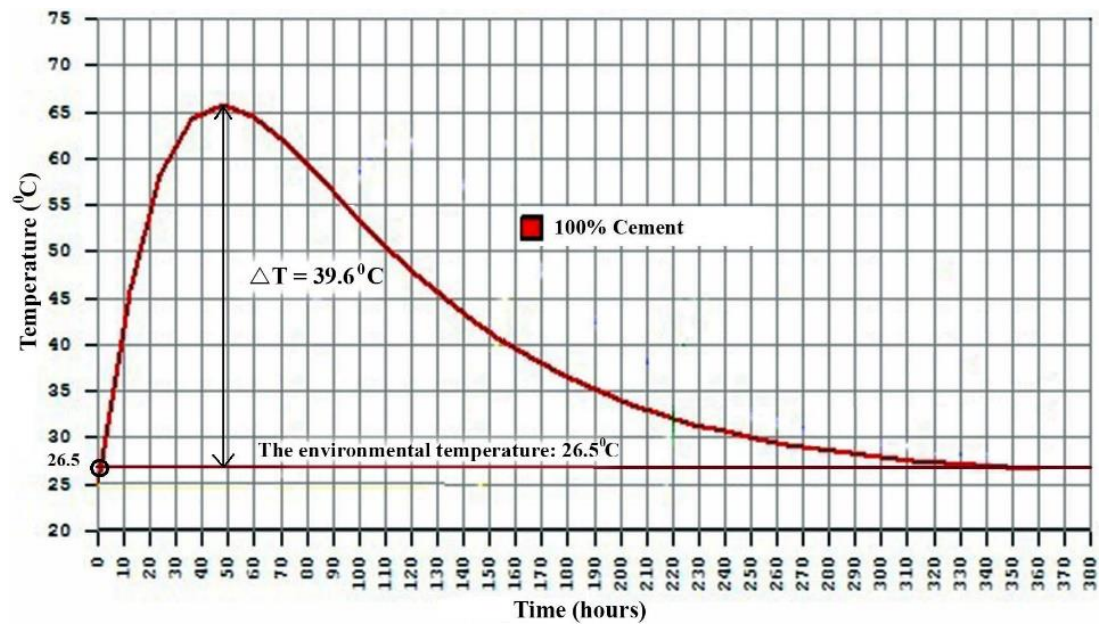

Fig. 6. Temperature evolutions at center of concrete block with $100 \%$ cement

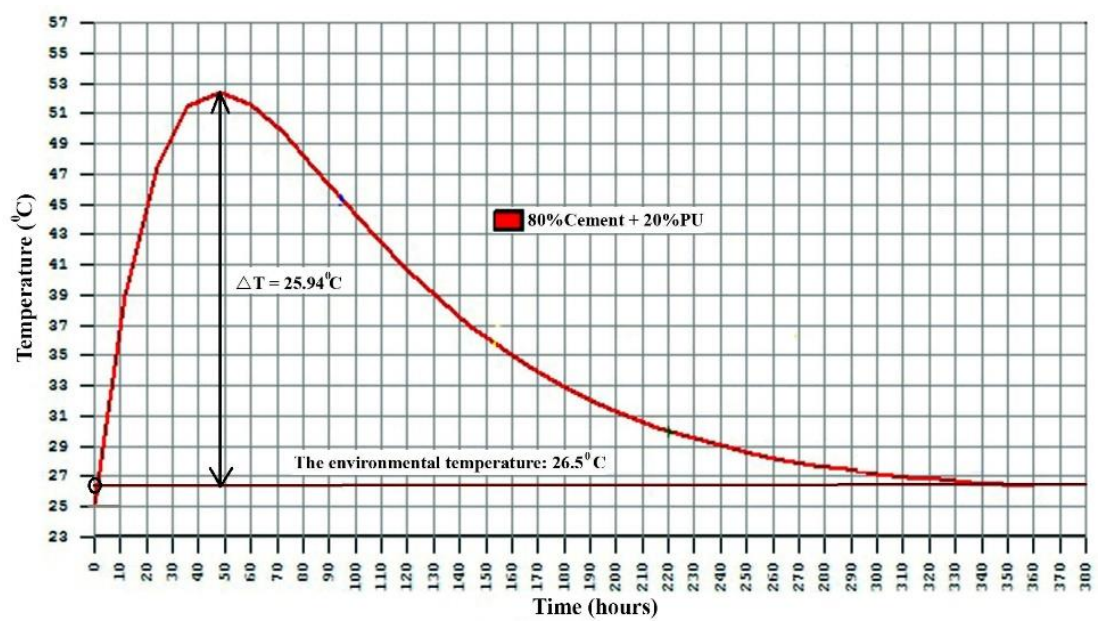

Fig. 7. Temperature evolutions at center of concrete block with $80 \%$ cement $+20 \% \mathrm{PU}$ 
Figure 8 shows three-dimensional model of the temperature distribution in body of the concrete blocks after 48 hours from the beginning of construction.
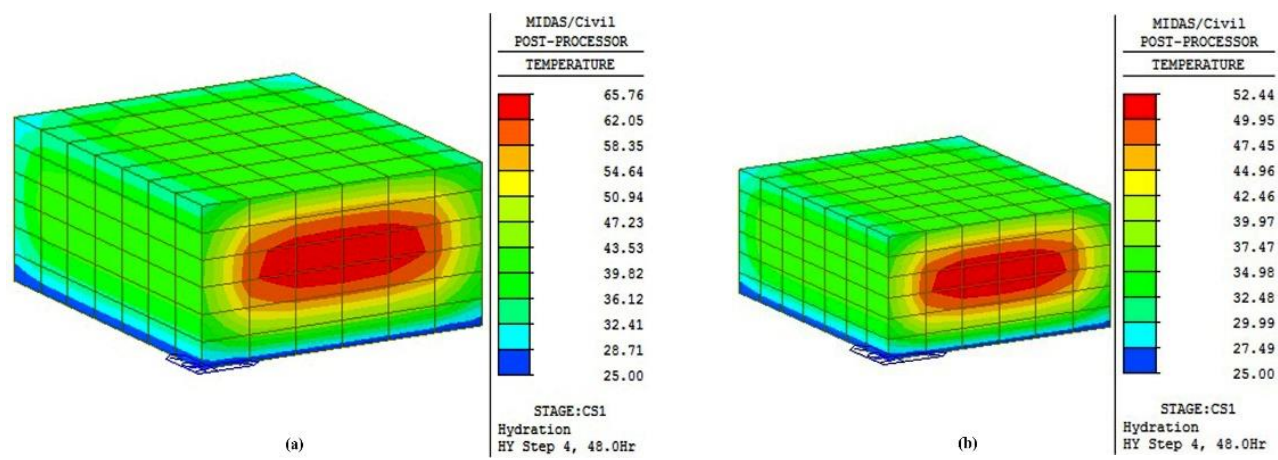

Fig. 8. 3D temperature distribution process in body of concrete block: (a) with composition of $100 \%$ cement and (b) with composition of $80 \%$ cement $+20 \%$ PU after 48 hours from the beginning of pouring

It can be noted from the Figures 6 - 8 that, the temperature at center of concrete block with $100 \%$ cement increases and reaches maximum temperature of $65.76^{\circ} \mathrm{C}$ after 48 hours from the beginning of pouring. Since then, it gradually decreases in the course of time hardening concrete due to the convective heat transfer at the boundaries. While, for concrete block with composition of $80 \%$ cement $+20 \%$ PU, heat in concrete body generates during the cement hydration increases and also reaches maximum temperature of $52.44^{\circ} \mathrm{C}$ after 48 hours from the beginning of pouring. Generally, with $20 \%$ of cement replacement by natural pozzolan resulted in reduction of temperature distribution and $25.4 \%$ reduction in the maximum temperature at center of the concrete using natural pozzolan.

Furthermore, it can be noted that cement hydration raises the temperature at the core of each concrete pours, producing considerably different temperatures with respect to the outer concrete portion, which induces risk of through cracking in body structure or surface. For concrete block with composition of $100 \%$ cement, the temperature difference between the central point and the environmental temperature $\Delta \mathrm{T}=39.26^{\circ} \mathrm{C}$, while this temperature difference for concrete block with composition of $80 \%$ cement $+20 \%$ PU is only $25.94^{\circ} \mathrm{C}$. Meaningfully, the risk of through thermal cracking of heavyweight concrete without pozzolan are higher than heavyweight concrete using natural pozzolan to replace $20 \%$ of mass cement.

\subsection{Estimation of the maximum temperature in the concrete using natural pozzolan}

In recent years, the most complete factor consideration for temperature problem solution possibly applies numerical methods, particularly, the finite element method through Midas Civil, Ansys, Adina, Abaqus programs and others. However, a quick estimation of the maximum temperature can be useful to determine the approximate temperature differential between the core and surface of the concretes.

The Portland Cement Association's (PCA) [20] design and control of concrete mixtures gives a quick method for estimating the maximum temperature developed in mass concrete members. This method calculates the maximum temperature rise above the concrete placement temperature as $12^{\circ} \mathrm{C}$ for every $100 \mathrm{~kg}$ of cement when the cement content is in the range of 300 to $600 \mathrm{~kg} / \mathrm{m}^{3}$ and the least dimension of the concrete member is $1.8 \mathrm{~m}$. According to ACI committee 207 [21] suggests that modification to account for 
supplementary cementitious materials can be made by presuming that they liberate approximately half of the amount of heat of cement for a given mass. The PCA calculation for the maximum concrete temperature $\left(\mathrm{T}_{\max }\right)$, taking into account this alteration for supplementary cementitious materials, is shown by equation (4):

$$
T_{\max }=T_{i}+\left(12 \frac{W_{\text {Cement }}}{100}\right)+\left(6 \frac{W_{\text {scm }}}{100}\right)
$$

where: $\mathrm{T}_{\mathrm{i}}$ - the concrete placement temperature $\left({ }^{0} \mathrm{C}\right)$;

$\mathrm{W}_{\text {cement }}$ - the cement content in $1 \mathrm{~m}^{3}$ concrete $(\mathrm{kg})$;

$\mathrm{W}_{\mathrm{scm}}$ - the supplementary cementitious materials content $\left(\mathrm{kg} / \mathrm{m}^{3}\right)$.

The approximate method of PCA (by Equation (4)) was used to estimate the peak temperature rise in the test specimens. The predicted maximum temperatures are presented in Table 6

Table 6. Predicted and measured maximum temperatures in body of heavyweight concretes

\begin{tabular}{|c|c|c|}
\hline \multirow{2}{*}{$\begin{array}{c}\text { Compositions of } \\
\text { concrete mixture }\end{array}$} & \multicolumn{2}{|c|}{ The maximum temperature $\left({ }^{\circ} \mathrm{C}\right)$} \\
\cline { 2 - 3 } & Calculated by Program Midas Civil & $\begin{array}{c}\text { Predicted by PCA (Equation } \\
(1))\end{array}$ \\
\hline $100 \%$ cement & 65.76 & 78.8 \\
\hline $80 \%$ cement $+2 \% \mathrm{PU}$ & 52.44 & 72.92 \\
\hline
\end{tabular}

Comparisons between the calculation and predicted temperatures show that the PCA method overestimated the maximum temperatures in concrete block, which determined by program Midas Civil. As a result, the predicted temperatures in the natural pozzolan concrete specimens are higher than the calculated temperatures by program.

\section{Conclusion}

Experimental work was carried out in the laboratory of Hanoi University of Mining and Geology to find out the effect of natural pozzolan from Northern part of Vietnam on the strength and hydration heat of heavyweight concrete. The standard TCVN $9382-2012$ (Vietnam) was used to determine the concrete mixture compositions. Concrete mix containing $490 \mathrm{~kg} / \mathrm{m}^{3}$ of cement and $20 \%$ mass of cement replacements were used in the study. The following conclusions are drawn from the experimental results:

1. Strengths of the natural pozzolan concrete were generally lower than those of control concrete. The average 28 -day compressive strengths of the concrete with $20 \%$ cement replacements by pozzolan was $87.7 \%$ of the strengths of the respective control concrete without pozzolan. The concrete compressive strength of composition of $80 \%$ cement $+20 \%$ PU decreases mostly by $30.1 \%$ at the age of 7 days and least by $12.3 \%$ at the age of 28 days in comparison to control concrete. However, natural pozzolan increases the workability of fresh concrete upto $16.67 \%$ as compared to control concrete.

2. By using the computer program Midas Civil, the maximum temperatures at center of concrete block with $100 \%$ cement and of concrete block with $80 \%$ cement $+20 \%$ PU are respectively $65.76^{\circ} \mathrm{C}$ and $52.44^{\circ} \mathrm{C}$ after 48 hours from the beginning of pouring. In addition, temperature difference between the central point and the environmental temperature of the control concrete with $100 \%$ Portland cement are higher than heavyweight concrete using $20 \%$ natural pozzolan. Meaningfully, the risk of through thermal cracking of heavyweight concrete without pozzolan are higher than heavyweight concrete using natural pozzolan to replace $20 \%$ of mass Portland cement. 
3. In accordance with quick method of PCA, the predicted temperatures of the concretes with $100 \%$ cement and with $80 \%$ cement $+20 \%$ PU were respectively $83.5 \%$ and $71.9 \%$ of the maximum temperatures, which calculated by program Midas Civil.

\section{Acknowledgement}

The authors wish to express their gratitude to the Faculty of Civil Engineering of Hanoi University of Mining and Geology for funding this work and other on-going research.

\section{References}

1. N.Q. Phu, N.T Le, Journal of Irrigation Science, 8 (2009)

2. T.V. Lam, B. Bulgakov, Y. Bazhenov, O. Aleksandrova, P.N. Anh, IOP Conf. Series: Materials Science and Engineering, 365 (2018), doi:10.1088/1757-899X/365/3/032007

3. T.V. Lam, B.I. Bulgakov, O.V. Aleksandrova, O.A. Larsen, P.N. Anh, E3S Web of Conferences 33, 02030 (2018), https://doi.org/10.1051/e3sconf/20183302030

4. P.K. Sarker, L. McKenzie, Strength and hydration heat of concrete using fly ash as a partial replacement. Proc. of 24th Biennial Conf. of the Concrete Inst. of Australia (2009)

5. T.V. Lam, B.I. Bulgakov, O.V. Aleksandrova, O.A. Larsen, Scientific and theoretical journal "Bulletin of BSTU. V.G. Shukhov", 6 (2017). DOI: 10.12737/article_5926a059214ca0.89600468

6. S.H. Sathawane, V.S. Vairagade, K.S. Kene, Combine Effect of Rice Husk Ash and Fly Ash on Concrete by 30\% Cement Replacement, Procedia Engineering, 51 (2013)

7. M. Liwu, D. Min, Thermal behavior of cement matrix with high-volume mineral admixtures at early hydration age, Cement and Concrete Research, 36 (2006)

8. M. Liwu, D. Min, Thermal behavior of cement matrix with high-volume mineral admixtures at early hydration age, Cem., Concr. Rese., 36 (2006)

9. R. Szecsy, Using High-Volume Fly Ash Concrete, Concr. Constru., 51 (2006)

10. R. Faria, M. Azenha, J.A. Figueiras, Modelling of concrete at early ages: Application to an externally restrained slab, Cem. Concr. Compos., 28 (2006)

11. Y. Lee, J-K. Kim, Numerical analysis of the early age behavior of concrete structures with a hydration based micro plane model, Comput. Struct., 87 (2009)

12. B. Klemczak, M. Batog, M. Pilch, A. Zmij, Analysis of Cracking Risk in Early Age Mass Concrete with Different Aggregate Types, Inter. Conf. Anal. Mod. and New Concep. Concr. Masonry Struc., AMCM, 193 (2017)

13. C.D. Atis, Heat Evolution of High Volume Fly Ash Concrete, Cement and Concrete Research, 32 (2002)

14. M.R. Jones, A. McCarthy, Heat of hydration in foamed concrete: Effect of mix constituents and plastic density, Cement and Concrete Research, 36 (2006)

15. A. Rahimi, J. Noorzaei, Thermal and Structural Analysis of Roller Compacted Concrete Dams by Finite Element Code. Australian Journal of Basic and Applied Sciences, 12 (2011)

16. J. Noorzaei, K.H. Bayagoob, A.A. Abdulrazeg, M.S. Jaafar, T.A. Mohammed, Three dimensional nonlinear temperature and structural analysis of roller compacted concrete dam, CMES, 1 (2009) 
17. M. Azenha, R. Faria, D. Ferreira, Identification of early-age concrete temperatures and strains: monitoring and numerical simulate ion, Cem. Concr. Comp., 31 (2009)

18. I. Abdallah, H. Malkawi, S.A. Mutasher, T.J. Qiu, Thermal - Structural Modeling and Temperature Control of Roller Compacted Concrete Gravity Dam, J. Perfor. of Constr., 17 (2003)

19. N. Q. Hung. Stress analysis of roller compacted concrete in the process of construction. J. Water Resou. Enviro. Sc., 22 (2009)

20. K.A. Riding, J.L. Poole, A.K. Schindler, M.C.G. Juenger, K.J. Follia rd, Evaluation of temperature prediction methods for mass concrete members, ACI Structural Journal, 103 (2006)

21. ACI Committee 207, Mass concrete (ACI 207.1R-96), (American concrete Institute, Farmington Hills, Michigan, 1996) 